\title{
Feedlot performance, feed efficiency and carcass traits in Nellore cattle selected for postweaning weight ${ }^{1}$
}

\author{
Tatiana Lucila Sobrinho², Sarah Figueiredo Martins Bonilha ${ }^{3}$, Heraldo Cesar Gonçalves ${ }^{2}$, André \\ Michel de Castilhos ${ }^{2}$, Elaine Magnani ${ }^{3}$, Alexander George Razook ${ }^{3}$, Renata Helena Branco ${ }^{3}$ \\ ${ }^{1}$ Projeto Financiado pela FAPESP. \\ ${ }^{2}$ Programa de Pós-graduação em Zootecnia, FMVZ/UNESP-Botucatu, SP. \\ ${ }^{3}$ Centro APTA Bovinos de Corte, Instituto de Zootecnia - Sertãozinho, SP.
}

\begin{abstract}
The objective of this study was to evaluate the correlated responses to selection for growth in feed efficiency and carcass traits of Nellore animals. A total of 121 animals of the Nellore control $(\mathrm{NeC})$ and selection herds were subjected to performance testing and classified regarding residual feed intake (RFI). Sixty-seven of these animals were selected and finished until reaching $4 \mathrm{~mm}$ of subcutaneous fat thickness between the 12th and 13th ribs. The animals were slaughtered at a mean age of 541 days and mean live weight of $423 \mathrm{~kg}$ for $\mathrm{NeS}$ and of $363 \mathrm{~kg}$ for $\mathrm{NeC}$, and carcass traits were measured. Animals in NeS presented higher initial and slaughter weights, dry matter intake, hot and cold carcass weight, weight of retail cuts, and carcass yield than $\mathrm{NeC}$ animals for the same slaughter age and feedlot time. No significant differences in RFI were observed between herds, showing that the weight gain from selection for growth did not cause changes in the energy efficiency of the animals.
\end{abstract}

Key Words: beef cattle, carcass yield, meat cuts, selection

\section{Introduction}

The beef cattle production system is constantly changing to meet the requirements of sustainable agriculture and consumer demands for meat quality. In this respect, various segments of the beef cattle industry are concentrating their efforts to improve product quality, to increase productivity, and to multiply profits. Considering the production system as a whole, once health and nutritional requirements are met, productivity basically depends on the genetic merit of the herd (Owens et al., 1995).

The main objective of the breeding program implemented at Centro APTA Bovinos de Corte is to increase the growth rates of Zebu (Nellore, Guzerat and Gyr) and taurine (Caracu) breeds by selection for postweaning weight. Several studies have investigated the genetic progress of growth traits in selected herds (Packer et al., 1986; Razook et al., 1988, 1993, 1998; Cyrillo et al., 2000). However, although direct responses in growth traits (weight, weight gain, carcass traits and others) have been analyzed since the beginning of the program, it has become important to monitor correlated changes in feed efficiency and carcass traits in the selected herds. Razook et al. (2001) showed that selection for postweaning weight resulted in higher slaughter and carcass weights without altering the yield or quality of the meat produced. Similar findings have been reported by Nardon (1998), who studied carcass traits in animals slaughtered at different weights, by Resende et al. (2000, 2001), who used different levels of concentrate in the diet, and by Vittori et al. (2006), who investigated the effect of castration. Furthermore, Bonilha et al. (2008), using the same genetic groups of Nellore but with a larger data set, observed that selection for weight increased the body size of the animals without altering meat yield, body fat percentage or meat tenderness.

The objective of the present study was to evaluate the correlated responses to selection for postweaning weight in feed efficiency and carcass traits of Nellore cattle.

\section{Material and Methods}

The study was carried out in the northern region of the state of São Paulo, located at $21^{\circ} 10^{\prime}$ South latitude and $48^{\circ} 05^{\prime}$ West longitude, classified according to Koppen as Aw, humid tropical climate, with average annual temperature of $24{ }^{\circ} \mathrm{C}$ and average annual rainfall of $1888 \mathrm{~mm}$.

The cattle herd of Centro APTA Bovinos de Corte was formed in 1933 and consists of purebred animals. In 1976, a selection program to increase postweaning weight was started, manipulating the equation of genetic gain within biological limits by selection based on individual performance (Razook et al., 1997). The genetic change in postweaning weights was then evaluated in relation to the Nellore control $(\mathrm{NeC})$ herd, which is basically subjected to 
stabilizing selection once the bulls and dams in this herd are selected according to a zero-reference differential of selection. In contrast, the Nellore selection $(\mathrm{NeS})$ herd is selected based on the highest selection differentials for weight adjusted to 378 days of age.

In the breeding program, the mating batches are formed with the same proportionality in terms of age of the dams, aiming to minimize endogamy. The breeding season lasts 3 months (from November to February) and a bull-to-cow ratio of 1:15 is used. The births occur between August and November. After weaning at 210 days, males undergo a feeding performance test according to the recommendations of Razook et al. (1997), where they remain until 378 days of age. Females are maintained on pasture until 550 days of age.

A total of 121 non-castrated Nellore males of the $\mathrm{NeC}$ and NeS herds, born between 2006 and 2007, participated in feeding performance tests between 2007 and 2008, respectively. The animals remained confined in individual stalls for 168 days (56 days of adaptation and 112 days of data collection).

After the end of the feeding performance test, in each year, residual feed intake (RFI), as proposed by Koch et al. (1963), was calculated as the difference between dry matter intake observed during the test period and the intake predicted by regression equations as a function of mean metabolic body weight and average daily gain. After this step, the animals were divided into classes according to RFI: high RFI ( $>$ mean $+0.5 \mathrm{SD}$; least efficient), medium $\mathrm{RFI}( \pm 0.5 \mathrm{SD}$ of the mean), and low RFI $(<$ mean $-0.5 \mathrm{SD}$; most efficient).

For the finishing phase, low and high RFI animals were selected in each year, corresponding to 33 animals in the first year $(22 \mathrm{NeS}$ and $11 \mathrm{NeC})$ and 34 in the second year (18 $\mathrm{NeS}$ and $16 \mathrm{NeC}$ ). Animals classified as medium RFI were excluded from this phase.

The animals then received a diet that contained $89 \%$ dry matter $(\mathrm{DM}), 14.8 \%$ crude protein $(\mathrm{CP})$ and consisted of Brachiaria hay, ground corn, cottonseed, citrus pulp, and mineral mix. Since one of the objectives of the study was to calculate nutritional requirements, the animals were randomly assigned to three feeding regimens. In each experiment, eight animals were slaughtered after a period of adaptation to the finishing diet, serving as the reference group. The remaining animals were divided into groups of three based on similar body weight and condition. Within each group of three, two feeding regimens were selected by drawing lots, with two animals fed ad libitum and one animal receiving a diet restricted to $65 \mathrm{~g} / \mathrm{kg}$ live weight in order to meet maintenance requirements.
Weight was recorded at the beginning of the experiment and at intervals of 14 days after a period of 16 hours of deprivation of solids. Ultrasound measures were obtained for the determination of backfat thickness, with a thickness of $4 \mathrm{~mm}$ between the 12th and 13th ribs used as the criterion for slaughter. The images were acquired and saved with a Pie Medical 401347-Aquila apparatus (Esaote Europe B.V.) equipped with a $3.5 \mathrm{MHz}$ linear probe $(18 \mathrm{~cm})$. For image acquisition, the transducer was positioned on the left side of the animal perpendicular to the spine between the 12th and 13th ribs using a standoff pad and vegetable oil as conductive medium. The images were processed and fat thickness was measured with the program Echo Image Viewer 1.0 (Pie Medical Equipment B.V., 1996).

The animals were slaughtered at a mean age of 541 days and mean live weight of $423 \mathrm{~kg}$ for $\mathrm{NeS}$ and of $363 \mathrm{~kg}$ for $\mathrm{NeC}$, after fasting from solid foods for approximately 16 hours. After weight recording, the animals were stunned by concussion, followed by suspension and bleeding through an incision in the jugular vein. Blood, head, hide, feet, tail, right and left half carcass, empty and clean viscera and the other internal organs were weighed for the determination of empty body weight.

The carcasses were kept in a cooling chamber at approximately $2{ }^{\circ} \mathrm{C}$ for 24 hours, weighed, and their length and depth were measured. The cooled right half carcasses were cut into forequarter (five ribs), spare ribs, and hindquarter, deboned and divided into the following retail cuts: striploin, tenderloin, rump, knuckle, topside (inside round), flat (outside round), eye round, flank steak, thin skirt, shoulder, neck, chuck, brisket, hump, hind- and foreshank and deboned and trimmed spare ribs. All retail cuts, as well as the trimmed parts and bones of each primary cut, were weighed individually.

Rib eye area and subcutaneous fat thickness were measured at the longissimus dorsi muscle between the 12th and 13th ribs. Hot and cold carcass yield was calculated as the ratio between carcass weight and live weight at slaughter. The proportions between hindquarter, forequarter and back ribs were calculated as the weight of each primary cut divided by cold carcass weight multiplied by 100 .

A completely randomized design was adopted. The variables year (experiments I and II) and diet (ad libitum and restricted) and their interactions were tested using the GLM procedure of the software SAS (Statistical Analysis System, version 8). Since the interactions were not significant, they were removed from the model and the data were analyzed together. Means were compared by the t-test, with the level of $5 \%$ of probability $(\mathrm{P}<0.05)$. 


\section{Results}

The animals were slaughtered at $405 \pm 51.1 \mathrm{~kg}$, at $541 \pm 35$ days of age, and at $84 \pm 30$ days in the feedlot (Table 1). There were large differences in the minimum and maximum values of feedlot time and age at slaughter due to the existence of the slaughter reference group, which was slaughtered immediately after adaptation to the diet. The mean RFI was $-0.009 \pm 0.337 \mathrm{~kg} /$ day (range: -0.640 to $+0.950 \mathrm{~kg} /$ day), confirming the existence of phenotypic variation in this trait in Nellore animals. The difference in dry matter intake between the most and least efficient animals was $1.59 \mathrm{~kg}$.

In the case of feedlot management in which about $80 \%$ of the costs are destined for feeding, the identification of animals that consume less feed without compromising production would result in major cost reductions for the system.

Despite the significant difference in dry matter intake, no significant differences in RFI $(P=0.247)$ were observed between animals of the control and selection herds.

Animals from NeS presented heavier empty body weight, higher hot and cold carcass weight, higher hot dressing percentage, and greater carcass length and depth than $\mathrm{NeC}$ animals (Table 2), as well as a trend $(\mathrm{P}=0.073)$ towards higher cold dressing percentage. The weights of primary and retail cuts also differed significantly between herds (Table 3).

Quantitative analysis of non-carcass parts is important, since these components exert a direct influence on carcass yield and weight gain. Internal fat weight (kidney, pelvic and heart) was similar and the weights of liver, kidney, gastrointestinal tract and other organs (sum of the

Table 1 - Means, standard deviations (SD), minimum and maximum values for performance and carcass traits and feed efficiency of Nellore bulls selected for postweaning weight

\begin{tabular}{lcccc}
\hline Traits & Means & SD & Minimum & Maximum \\
\hline Slaughter age, d & 541 & 35.2 & 454 & 612 \\
Feedlot time, d & 84.1 & 29.9 & 41.0 & 126 \\
Dry matter intake, kg DM/d & 6.74 & 1.36 & 4.06 & 10.2 \\
Average daily gain, kg BW/d & 0.744 & 0.262 & -0.100 & 1.37 \\
Residual feed intake, kg DM/d & -0.009 & 0.337 & -0.640 & 0.950 \\
Initial body weight, kg & 344 & 37.0 & 250 & 413 \\
Body weight at slaughter, kg & 405 & 51.1 & 285 & 501 \\
Shrunk body weight, kg & 373 & 48.2 & 261 & 469 \\
Hot carcass weight, kg & 248 & 34.2 & 167 & 319 \\
Cold carcass weight, kg & 244 & 33.7 & 165 & 314 \\
Hot dressing percentage, \% & 61.2 & 1.39 & 58.0 & 63.9 \\
Cold dressing percentage, \% & 60.1 & 1.37 & 56.5 & 63.1 \\
Carcass length, cm & 120 & 5.17 & 106 & 131 \\
Carcass depth, cm & 39.6 & 1.89 & 35.4 & 43.6 \\
\hline DM - dry matter; BW - body weight. & & & &
\end{tabular}

DM - dry matter; BW - body weight. reproductive tract, heart, lungs, trachea, esophagus, and spleen) were higher in $\mathrm{NeS}$ than in $\mathrm{NeC}$ animals (Table 4).

Table 2 - Means of performance and carcass traits and feed efficiency of Nellore bulls selected for postweaning weight

\begin{tabular}{lcccc}
\hline \multirow{2}{*}{ Traits } & \multicolumn{2}{c}{ Herd } & & \\
\cline { 2 - 3 } & $\mathrm{NeS}$ & $\mathrm{NeC}$ & & $\mathrm{P}$ \\
\hline $\mathrm{n}$ & 40 & 27 & --- & --- \\
Slaughter age, d & $530 \mathrm{a}$ & $542 \mathrm{a}$ & 4.82 & 0.084 \\
Feedlot time, d & $80.6 \mathrm{a}$ & $76.3 \mathrm{a}$ & 22.1 & 0.384 \\
Dry matter intake, kg DM/d & $7.13 \mathrm{a}$ & $5.97 \mathrm{~b}$ & 10.9 & $<0.001$ \\
Average daily gain, kg BW/d & $0.784 \mathrm{a}$ & $0.659 \mathrm{a}$ & 33.1 & 0.061 \\
Residual feed intake, kg DM/d & $-0.004 \mathrm{a}$ & $-0.062 \mathrm{a}$ & $1.95 \mathrm{E}-3$ & 0.247 \\
Initial body weight, kg & $363 \mathrm{a}$ & $316 \mathrm{~b}$ & 8.62 & $<0.001$ \\
Body weight at slaughter, kg & $423 \mathrm{a}$ & $363 \mathrm{~b}$ & 9.49 & $<0.001$ \\
Shrunk body weight, kg & $388 \mathrm{a}$ & $335 \mathrm{~b}$ & 9.87 & $<0.001$ \\
Hot carcass weight, kg & $259 \mathrm{a}$ & $220 \mathrm{~b}$ & 10.3 & $<0.001$ \\
Cold carcass weight, kg & $255 \mathrm{a}$ & $217 \mathrm{~b}$ & 10.4 & $<0.001$ \\
Hot dressing percentage, \% & $61.2 \mathrm{a}$ & $60.5 \mathrm{~b}$ & 2.08 & 0.047 \\
Cold dressing percentage, \% & $60.2 \mathrm{a}$ & $59.6 \mathrm{a}$ & 2.11 & 0.073 \\
Carcass length, cm & $123 \mathrm{a}$ & $115 \mathrm{~b}$ & 2.71 & $<0.001$ \\
Carcass depth, cm & $40.5 \mathrm{a}$ & $38.1 \mathrm{~b}$ & 3.69 & $<0.001$ \\
\hline
\end{tabular}

Means followed by a different letter in the row differ $(\mathrm{P}<0.05)$ by least squares means adjusted for the $t$ test (Pdiff).

SD - standard deviation; DM - dry matter; BW - body weight; NeS - animals of selection; $\mathrm{NeC}$ - animals of control.

Table 3 - Proportions and commercial cuts of Nellore bulls selected for postweaning weight

\begin{tabular}{lcccr}
\hline & \multicolumn{2}{c}{ Herd } & & \\
\cline { 2 - 3 } Traits & $\mathrm{NeS}$ & $\mathrm{NeC}$ & & \\
\hline Primary cuts, $\mathrm{kg}$ & & & & \\
Hindquarter & $60.9 \mathrm{a}$ & $50.8 \mathrm{~b}$ & 9.48 & $<0.001$ \\
Forequarter & $51.8 \mathrm{a}$ & $44.6 \mathrm{~b}$ & 12.0 & $<0.001$ \\
Spare ribs & $18.1 \mathrm{a}$ & $15.3 \mathrm{~b}$ & 14.6 & $<0.001$ \\
Proportions, \% & & & & \\
Hindquarter & $47.8 \mathrm{a}$ & $46.9 \mathrm{a}$ & 3.74 & 0.078 \\
Forequarter & $40.6 \mathrm{a}$ & $41.2 \mathrm{a}$ & 4.18 & 0.176 \\
Spare ribs & $11.6 \mathrm{a}$ & $11.9 \mathrm{a}$ & 3.74 & 0.904 \\
Hindquarter cuts, kg & & & & \\
Striploin & $6.63 \mathrm{a}$ & $5.91 \mathrm{~b}$ & 11.6 & $<0.001$ \\
Tenderloin & $2.02 \mathrm{a}$ & $1.70 \mathrm{~b}$ & 21.7 & 0.005 \\
Rump & $5.61 \mathrm{a}$ & $4.89 \mathrm{~b}$ & 12.5 & $<0.001$ \\
Knuckle & $5.06 \mathrm{a}$ & $4.15 \mathrm{~b}$ & 11.7 & $<0.001$ \\
Topside & $8.58 \mathrm{a}$ & $7.08 \mathrm{~b}$ & 10.9 & $<0.001$ \\
Flat & $5.11 \mathrm{a}$ & $4.45 \mathrm{~b}$ & 11.4 & $<0.001$ \\
Eye round & $2.44 \mathrm{a}$ & $2.02 \mathrm{~b}$ & 11.6 & $<0.001$ \\
Flank steak & $1.03 \mathrm{a}$ & $0.913 \mathrm{~b}$ & 22.1 & 0.055 \\
Shank & $3.63 \mathrm{a}$ & $2.96 \mathrm{~b}$ & 10.1 & $<0.001$ \\
Thin skirt & $3.01 \mathrm{a}$ & $2.60 \mathrm{~b}$ & 21.3 & 0.018 \\
Forequarter cuts, kg & & & 17.45 & \\
Shoulder & $11.3 \mathrm{a}$ & $9.04 \mathrm{~b}$ & 12.9 & $<0.001$ \\
Neck & $4.80 \mathrm{a}$ & $3.96 \mathrm{~b}$ & 17.5 & $<0.001$ \\
Chuck & $8.59 \mathrm{a}$ & $7.41 \mathrm{~b}$ & 19.4 & 0.008 \\
Brisket & $4.62 \mathrm{a}$ & $4.05 \mathrm{~b}$ & 20.3 & 0.018 \\
Hump & $1.89 \mathrm{a}$ & $2.10 \mathrm{a}$ & 30.1 & 0.193 \\
Shank & $3.02 \mathrm{a}$ & $2.59 \mathrm{~b}$ & 14.9 & $<0.001$ \\
Spare ribs cuts, kg & & & & \\
Spare ribs & $8.38 \mathrm{a}$ & $6.96 \mathrm{~b}$ & 15.6 & $<0.001$ \\
\hline & & & & \\
\hline
\end{tabular}

Means followed by a different letter in the row differ $(\mathrm{P}<0.05)$ by least squares means adjusted for the $t$ test (Pdiff).

$\mathrm{SD}$ - standard deviation; $\mathrm{NeS}$ - animals of selection; $\mathrm{NeC}$ - animals of control. 
Table 4 - Average weight of organs of Nellore bulls selected for postweaning weight

\begin{tabular}{lcccc}
\hline \multirow{2}{*}{ Traits } & \multicolumn{2}{c}{ Herd } & \multirow{2}{*}{ SD } & P \\
\cline { 2 - 4 } & $\mathrm{NeS}$ & $\mathrm{NeC}$ & & \\
\hline Liver, $\mathrm{kg}$ & $4.67 \mathrm{a}$ & $4.11 \mathrm{~b}$ & 12.8 & $<0.001$ \\
Kidney, kg & $0.863 \mathrm{a}$ & $0.620 \mathrm{~b}$ & 17.5 & $<0.001$ \\
KPH, kg & $6.03 \mathrm{a}$ & $6.77 \mathrm{a}$ & 37.8 & 0.278 \\
GIT, kg & $25.2 \mathrm{a}$ & $23.1 \mathrm{~b}$ & 14.6 & 0.035 \\
Other organs, kg & $11.7 \mathrm{a}$ & $10.5 \mathrm{~b}$ & 11.6 & 0.001 \\
\hline KPH - kidney, pelvic and heart fat; $\mathrm{GIT}-$ gastrointestinal tract; SD & - standard \\
deviation; NeS - animals of selection; NeC - animals of control. & \\
Means followed by different letters differ (P<0.05) by least squares means adjusted \\
for the t test (Pdiff). \\
${ }^{1}$ Reproductive tract + heart + lungs + trachea + weasand meat + spleen.
\end{tabular}

Table 5 - Rib eye area and backfat thickness of the longissimus dorsi muscle of Nellore bulls selected for postweaning weight

\begin{tabular}{|c|c|c|c|c|}
\hline \multirow{2}{*}{ Traits } & \multicolumn{2}{|c|}{ Herd } & \multirow{2}{*}{$\mathrm{SD}$} & \multirow{2}{*}{$\mathrm{P}$} \\
\hline & $\mathrm{NeS}$ & $\mathrm{NeC}$ & & \\
\hline $\mathrm{BFT}, \mathrm{mm}^{1}$ & $3.74 \mathrm{a}$ & $3.96 \mathrm{a}$ & 24.1 & 0.406 \\
\hline $\mathrm{BFT}, \mathrm{mm}$ & $3.49 \mathrm{a}$ & $3.93 a$ & 36.7 & 0.241 \\
\hline REA $\mathrm{cm}^{2}$ & $75.4 \mathrm{a}$ & $72.1 \mathrm{a}$ & 12.9 & 0.213 \\
\hline $\mathrm{REA}, \mathrm{cm}^{2} / 100 \mathrm{~kg}$ carcass & $29.9 \mathrm{~b}$ & $33.3 \mathrm{a}$ & 10.6 & $<0.001$ \\
\hline
\end{tabular}

Means followed by a different letter differ $(\mathrm{P}<0.05)$ by least squares means adjusted for the t test (Pdiff).

BFT - backfat thickness; REA - rib eye area; SD - standard deviation; NeS - animals of selection; $\mathrm{NeC}$ - animals of control.

${ }^{1}$ Measured by ultrasound.

No significant difference in rib eye area was observed between the selection and control herds (Table 5). However, when the measure was reported per $100 \mathrm{~kg}$ carcass, a higher mean was observed for $\mathrm{NeC}$ animals due to the lower carcass weight of these animals.

\section{Discussion}

With respect to variables related to body size, there was a wide variation in minimum and maximum values due to the differences between the $\mathrm{NeC}$ and $\mathrm{NeS}$ herds resulting from the divergent selection for growth applied to these herds for more than 30 years. According to Mercadante et al. (2004), selection for weight promoted a difference of approximately $60 \mathrm{~kg}$ between the Nellore herds raised at Instituto de Zootecnia in Sertãozinho.

According to Dittmar III (2007), RFI takes into account the energy requirements for maintenance and production and is more sensitive to variations in individual energy efficiency of the animals. As a consequence, selection for growth resulted in animals of larger body size and with higher dry matter intake. These animals presented a tendency $(\mathrm{P}=0.061)$ towards higher weight gain rates but similar energy efficiencies. This shows that the selection applied to the Nellore herds of Instituto de Zootecnia over the last 30 years did not cause changes in the energy efficiency of the animals.
Animals from $\mathrm{NeS}$ presented a higher slaughter weight than $\mathrm{NeC}$ animals and reached the criterion recommended for slaughter (4 $\mathrm{mm}$ of subcutaneous fat thickness between the 12th and 13th ribs) at a similar age and during the same feedlot time. This finding shows that selection for growth of these herds resulted in animals that were superior in terms of slaughter weight without compromising physiological maturity. This superiority is in agreement with Razook et al. (1998), who reported an annual genetic progress of $1.1 \%$.

Razook et al. (2002), studying the same genetic groups finished on pasture, concluded that selection for weight resulted in heavier animals at slaughter, with a consequent superiority in carcass weight without alterations in hot and cold dressing percentage, meat tenderness or cooking losses, but with lower subcutaneous fat thickness in the longissimus muscle. In a meta-analysis of carcass traits in genetic groups selected for growth using a robust data set (490 animals), Bonilha et al. (2008) showed that selection for postweaning weight was truly effective, giving origin to larger animals with superior carcass weight and retail cuts, but did not cause correlated changes in dressing percentage or body fat content.

When analyzing the market conditions of beef meat, it is not economically interesting for the meat processing plant to slaughter animals of the same age and with lower live and carcass weights since profitability of the sector depends on the volume of commercialization of the meat product. However, considering meat quality, Bonilha et al. (2007) observed a lower shear force value ( 3.17 vs. $4.25 \mathrm{~kg}$ ) in NeC animals when compared with $\mathrm{NeS}$ animals, although the values obtained for the latter were within the reference range indicative of tender meat. In a subsequent study including a much larger data set, the same authors found no significant differences in meat shear force values between the control and selection Nellore herds of Centro APTA Bovinos de Corte, Instituto de Zootecnia (Bonilha et al., 2008).

The significant differences in carcass traits observed between $\mathrm{NeS}$ and $\mathrm{NeC}$ animals are the result of correlated changes in response to selection for growth. In addition to other factors, heavier carcasses with higher hindquarter yield are commercially more profitable since the most valuable cuts are found in this part of the carcass. No significant difference between the control and selection herds was only observed for the hump forequarter cut. Nardon (1998) and Bonilha et al. (2007) also found no significant differences in hump cut between the $\mathrm{NeC}$ and $\mathrm{NeS}$ herds of Instituto de Zootecnia.

A high coefficient of variation was obtained for kidney, pelvic and heart fat, demonstrating the existence of wide 
variation in the values observed (range: 2.8 to $13.8 \mathrm{~kg}$ ). This fact might explain the lack of a significant difference in this trait between herds. Nardon (1998) also found no significant difference in the percentage or quantity of internal fat between the control and selection herds. Organ weight seems to be intimately related to the size of the animal. In this respect, animals with a higher slaughter weight also present higher weights of other organs such as liver, kidneys and gastrointestinal tract.

Morris et al. (1993), studying Angus cattle selected for growth, found no significant differences in rib eye area between selected and control herds. No significant differences in subcutaneous fat thickness between $\mathrm{NeS}$ and $\mathrm{NeC}$ animals was observed in this study, as well. Bonilha et al. (2007) also found no significant differences in subcutaneous fat thickness between control and selection herds, but the values reported by those authors were higher than those observed in the present study.

\section{Conclusions}

In addition to changes in the growth potential of the animals, giving origin to heavier animals, selection for postweaning weight applied to herds promotes positive correlated responses in carcass traits without causing changes in the energy efficiency of the animals.

\section{References}

BONILHA, S.F.M.; PACKER, I.U.; FIGUEIREDO, L.A. et al. Efeitos da seleção para peso pós-desmame sobre características de carcaça e rendimento de cortes carneos comerciais de bovinos. Revista Brasileira de Zootecnia, v.36, n.5, p.1275-1281, 2007.

BONILHA, S.F.M.; TEDESCHI, L.O.; PACKER, I.U. et al. Evaluation of carcass characteristics of Bos indicus and tropically adapted Bos taurus breeds selected for postweaning weight. Journal of Animal Science, v.86, p.1770-1780, 2008.

CYRILLO, J.N.S.G.; RAZOOK, A.G.; FIGUEIREDO, L.A. et al. Efeitos da seleção para peso pós-desmame sobre medidas corporais e perímetro escrotal de machos Nelore de Sertãozinho (SP). Revista Brasileira de Zootecnia, v.29, n.2, p.403-412, 2000.

DITTMAR III, R.O. Determining biological sources of variation in residual feed intake in Brahman heifers during confinement feeding and on pasture. 2007. 111p. Degree of Master of Science (Animal Science) - Texas A\&M University, Texas.

KOCH, R.M.; SWIGER, L.A.; CHAMBERS, D. et al. Efficiency of feed use in beef cattle. Journal of Animal Science, v.22, p.486-494, 1963.

MERCADANTE, M.E.Z.; RAZOOK, A.G.; CYRILLO, J.N.S.G. et al. Programa de Seleção da Estação Experimental de Zootecnia de Sertãozinho: resultados de pesquisas, sumário de touros Nelore. Nova Odessa: Instituto de Zootecnia, 2004. 35p. (Boletim científico, 12).

MORRIS, C.A.; BAKER, R.L.; BASS, J.J. et al. Carcass composition in weight-selected and control bulls from a serial slaughter experiment. Australian Journal of Agricultural Research, v.44, n.2, p.199-213, 1993.

NARDON, R.F. Seleção de bovinos para desempenho: composição corporal e características de carcaça. 1998. 99f. Tese (Doutorado em Zootecnia) - Universidade Estadual Paulista, Jaboticabal.

OWENS, F.N.; GILL, D.R.; SECRIST, D.S. et al. Review of some aspects of growth and development of feedlot cattle. Journal of Animal Science, v.73, n.10, p.3152-3172, 1995.

PACKER, I.U.; RAZOOK, A.G.; TROVO, J.B.F. et al. Selection for yearling weight in Nelore and Guzerá Zebu breeds: Selection applied and responses. In: INTRODUCTION BREEDING PROGRAMS FOR DAIRY AND BEEF CATTLE, SHEEP AND GOATS, WATER BUFFALO, 9., 1986, Nebraska. Proceedings... Nebraska: World Congress on Genetics Applied To Livestock Production, 1986. p.419-423.

RAZOOK, A.G.; BONILHA NETO,L.M.; FIGUEIREDO, L.A. et al. Seleção para peso pós-desmama em bovinos Nelore e Guzerá. II. Respostas diretas e correlacionadas. Boletim da Indústria Animal, v.45 n.2, p.241-271, 1988.

RAZOOK, A.G.; FIGUEIRREDO, L.A.; TROVO, J.B.F. et al. Intensidades de seleção e respostas direta e correlacionadas em 10 anos de progênies de bovinos das raças Nelore e Guzerá selecionados para peso pós-desmame. Boletim da Indústria Animal, v.50, n.2, p.147-163, 1993.

RAZOOK, A.G.; FIGUEIREDO, L.A.; CYRILLO, J.N.S.G. et al. Prova de ganho de peso: normas adotadas pela estação experimental de Zootecnia de Sertãozinho. Nova Odessa: Instituto de Zootecnia, 1997. 33p. (Boletim técnico, 40).

RAZOOK, A.G.; FIGUEIREDO, L.A.; BONILHA NETO, L.M. Selection for yearling weigth in Nelore and Guzerá zebu breeds: selection applied and response. in 15 years of progeny. In: WORLD CONGRESS ON GENETICS APPLIED TO LIVESTOCK PRODUCTION, 6., 1998, Armidale. Proceedings... Armidale: New South Wales, 1998. p.133-136.

RAZOOK, A.G.; FIGUEIREDO, L.A.; NARDON, R.F. et al. Efeitos de raça e da seleção para peso pós-desmame sobre características de confinamento e de carcaça da 15a progênie dos rebanhos Zebu e Caracu de Sertãozinho (SP). Revista Brasileira de Zootecnia, v.30, n.1, p.115-124, 2001.

RAZOOK, A.G.; FIGUEIREDO, L.A.; RUGGIERI, A.C. et al. Desempenho em pastagens e características de carcaça da $16^{\mathrm{a}}$ progênie dos rebanhos Nelore, Guzerá e Caracu de Sertãozinho (SP). Revista Brasileira de Zootecnia, v.31, n.3, p.1367-1377, 2002.

RESENDE, F.D.; NARDON, R.F.; RAZOOK, A.G. et al. Desempenho e características de carcaça de zebuínos e caracu selecionados para peso aos 378 dias de idade, submetidos a dois níveis de energia na terminação. In: REUNIÃOANUALDA SOCIEDADE BRASILEIRA DE ZOOTECNIA, 37., 2000, Viçosa, MG. Anais...Viçosa, MG: Sociedade Brasileira de Zootecnia/Gnosis, 2000. (CD-ROM).

RESENDE, F.D. Peso ideal ao abate. In: ENCONTRO TERRA NOVA DE PECUARIA, 4., 2001, Rio Preto. Anais... Rio Preto - SESC - Fazenda do Instituto de Zootecnia de São José do Rio Preto, 2001. 143p.

VITTORI, A.; QUEIROZ, A.C.; REZENDE, F.D. et al. Características de carcaça de bovinos de diferentes grupos genéticos, castrados e não-castrados, em fase de terminação. Revista Brasileira de Zootecnia, v.35, n.5, p.2085-2092, 2006. 